\title{
A biological and economic comparison of 2 pasture-based production systems on a wetland drumlin soil in the northern region of Ireland
}

\author{
D. Patton, ${ }^{*} \dagger^{1}$ L. Shalloo, ${ }^{*}$ K. M. Pierce, $\dagger$ and B. Horan ${ }^{\star}$ \\ *Animal and Grassland Research and Innovation Centre, Teagasc Moorepark, Fermoy, Co. Cork, Ireland \\ †School of Agriculture, Food Science and Veterinary Medicine, University College Dublin, Belfield, Dublin 4, Ireland
}

\begin{abstract}
The objective of this study was to compare the biological and economic efficiencies of 2 likely future pasture-based systems of milk production differing in overall stocking rate and concentrate supplementation level on a wetland drumlin soil in the Border Midlands Western region of Ireland. Physical performance data were obtained from a 3-yr systems comparison at Ballyhaise College, Co. Cavan, comparing 2 production systems: a high grass (HG) system (578 kg of concentrate/ cow at 2.45 livestock units per hectare) and a high intensity (HI) system (1,365 $\mathrm{kg}$ of concentrate/cow at 2.92 livestock units/ha). Animal production data were analyzed using a mixed model, with feed system, year, and parity included as fixed effects in the final model. Feed system had a significant effect on all yield variables with higher yields in the HI system. Production system had no significant influence on reproductive performance. The Moorepark Dairy Systems Model, a stochastic budgetary simulation model, was used to simulate a model farm integrating biological data from each feed system to identify the economic effect of each system at 3 future milk prices of 22, 27, and 33 euro cents per liter $(€ \mathrm{c} / \mathrm{L})$. Two economic scenarios were investigated within the model: scenario 1 (S1) assumed fixed cow numbers $(\mathrm{n}=55$ cows) and scenario $2(\mathrm{~S} 2)$ assumed fixed land area $(\mathrm{n}=40 \mathrm{ha})$. At a milk price of 27 or $33 € \mathrm{c} / \mathrm{L}$, profit per cow, per kilogram of milk solids, and per hectare were similar for $\mathrm{HG}$ and $\mathrm{HI}$ in $\mathrm{S} 1$ and higher for $\mathrm{HI}$ in S2. At a milk price of $22 \mathrm{\epsilon c} / \mathrm{L}$, all systems were unprofitable, with increased losses realized in the HI system (both S1 and S2) compared with the HG system. Pasture-based systems of milk production in the northern region of Ireland are capable of highly efficient and profitable milk production. Moreover, the efficacy of increased supplementation to remove the constraints of pasture seasonality will
\end{abstract}

Received May 20, 2011.

Accepted August 19, 2011.

${ }^{1}$ Corresponding author: donal.patton@teagasc.ie depend on the cost of supplementation and the price paid for additional milk produced.

Key words: pasture-based production, wetland soil, productivity, profitability

\section{INTRODUCTION}

The European Union (EU) Common Agricultural Policy (CAP) set up in 1957 aimed to guarantee food security at stable and reasonable prices to producers by protecting domestic agriculture from foreign competitors (Whetstone, 1999). European Union milk quotas were introduced in 1984 to control the costs of CAP policy by limiting milk production and reducing the amount of surplus product that needed to be sold on the world market. Although the policy resulted in stable and high prices for EU producers, it constrained the development of the EU dairy sector. Reforms to the CAP have recently led to an agreement to abolish EU milk quotas by 2015. The abolition of quotas is anticipated to result in lower and more volatile milk prices to producers (Breen and Hennessy, 2003) while allowing milk production within Europe to move to areas of increased competitive advantage, such as Ireland (Lips and Rieder, 2005).

The realization of significant expansion in milk production in Ireland will require increased productivity from pasture. Similar adaptations have occurred in other countries and are characterized by increased stocking densities (Philpott, 1995) and strategic supplementation with external feed resources (Bargo et al., 2003) to increase production efficiency. In the future, land availability on existing dairy farms will limit milk production expansion (O'Donnell et al., 2008), whereas productivity per unit of available feed will be increasingly important (Shalloo et al., 2004c). In addition to increased grass production and utilization on existing dairy farms, new dairy enterprises may emerge outside of the existing milk production regions on more marginal soil types such as those reported by Shalloo et al. (2004a). The Border, Midland, and Western region of Ireland (BMW; www.bmwassembly.ie/) comprises 13 counties, including the 6 counties that border Northern 
Ireland, and accounts for $47 \%$ of national land area. Notwithstanding its scale, the region currently accounts for only $25 \%$ of total national milk production (CSO, 2009). From an agronomic perspective, the wet mineral soils characteristic of the region impede drainage and result in a shorter grazing season and lower pasture production compared with those in the south of Ireland (Brereton and Hope-Cawdrey, 1988).

Many studies have focused on the potential of increased stocking rates (SR, traditionally measured as cows per hectare; McMeekan and Walshe, 1963; Macdonald et al., 2008) and increased feed supplementation (Kellaway and Porta, 1993; Horan et al., 2005) to increase productivity within pasture systems. However, few studies have focused on the implications of alternative grazing systems differing in SR and feed supplementation level specifically within soil types such as those found in the BMW region. Ryan (1974) and Thomasson (1979) observed that DM production was reduced by up to $25 \%$ in poorly drained soils, whereas Shalloo et al. (2004a) estimated that the average farm profitability of a wetland soil type ranged from 38 to $58 \%$ of that achievable on drier southern soils. Shalloo et al. (2004a) also concluded that milk production systems under such conditions would be unsustainable because of reduced productivity per cow, increased production costs, and increased capital requirements associated with such systems.

The objective of this study was therefore to compare the biological and economic efficiencies of 2 likely future pasture-based production systems of spring milk production differing in overall SR and concentrate supplementation level on a wetland drumlin soil. The experimental hypothesis was that an intensified system of production based on increased concentrate supplementation in conjunction with an increase in overall SR would be more productive and profitable.

\section{MATERIALS AND METHODS}

This study was carried out at Ballyhaise College $\left(54^{\circ} 051^{\prime} \mathrm{N}, 07^{\circ} 031^{\prime} \mathrm{W}\right)$ in the Republic of Ireland over a 3-yr period from 2005 to 2007 . The experimental site comprises a variety of soil types, including alluvials, brown earths, brown podzolics, and gleys on a lower Silurian sandstone bedrock. The bedrock is overlain by drumlin-shaped mounds of stony, slowly permeable boulder clay and by gently sloping areas of glacial drift. The topography ranges from alluvial flatlands (along the Annalee River, which transects the site) to recurrent drumlins of various shapes, with steep slopes $\left(9^{\circ}\right.$ to $18^{\circ}$ ) and intervening U-shaped valleys. The levees, which run contiguous to the riverbanks, are mostly brown earth soils and are moderately well drained. The area between the levees and the lower slopes of the drumlins are level and are mainly poorly drained. This poor drainage is caused by the high groundwater table, very slow surface water run-off, and the slow permeability of the soil resulting from its poor structure and sticky consistency.

\section{Animals}

Data were collected from 68,81 , and 91 animals in 2005, 2006, and 2007, respectively. Holstein-Friesian animals constituted 100,79 , and $65 \%$ of the phenotypes in 2005, 2006, and 2007, respectively with the remainder of the animals of Norwegian Red and Norwegian Red and Jersey crosses with cows of Holstein-Friesian origin in 2006 and 2007. All animals had received genetic evaluation values using the Irish genetic evaluation system (Economic Breeding Index; EBI) at the time of the study. The average EBI of the experimental animals was €45 during the study (ICBF, 2005-2007), which was equivalent to the average EBI of the national herd during the same period. The mean predicted differences for the herd obtained from the November 2007 international evaluations of the Animal Centre (Interbull, Uppsala, Sweden) using multi-trait across-country evaluation were 107 (SD 319) $\mathrm{kg}$ of milk, 5.4 (SD 14) $\mathrm{kg}$ of fat, 5.6 (SD 11.1) $\mathrm{kg}$ of protein, 0.03 (SD 0.034) $\mathrm{g}$ of fat $/ \mathrm{kg}$, and 0.04 (SD 0.16) g of protein $/ \mathrm{kg}$. In year 1 , the experimental animals were assigned to 1 of the 2 feed groups before calving based on parity, calving date, previous milk yield, BCS, BW, and genetic merit (EBI). All multiparous animals were subsequently retained on the same feeding system for the duration of the study. Primiparous animals entering the study were randomly assigned to feed treatment based on EBI, breed, calving date, and precalving BW and BCS. Because experimental herd size was increased each year, first-lactation animals constituted 22,30 , and $49 \%$ of the herd in 2005, 2006, and 2007, respectively.

\section{Feed Systems and Grazing Management}

All multiparous animals were randomly allocated to 1 of 2 possible post-EU-quota, pasture-based feed systems (FS): (1) the high grass (HG) system; a high grass allowance, high SR (2.45 cows/ha), and low concentrate input $(578 \mathrm{~kg} / \mathrm{cow})$ system, and (2) a high output per hectare (HI) system, with a higher SR (2.92 cows/ha) system and an increased concentrate input $(1,365 \mathrm{~kg} / \mathrm{cow})$. The HG FS was designed as a lowcost pasture management system for a post-EU-quota scenario based on high levels of pasture utilization and a low level of concentrate supplementation. The HI FS was created as a high-productivity pasture system 
to increase milk output per hectare by supplementing pasture with concentrates and increasing SR to ensure similar high levels of pasture utilization. The ingredient composition of the concentrate feed $(\mathrm{kg} / \mathrm{t}$ as fed) was as follows: barley 250, corn gluten 260, beet pulp 350 , soybean meal 110 , and minerals plus vitamins 30 . Each FS was also defined in terms of comparative SR (Macdonald et al., 2008) as an alternate measure of FS intensity. Comparative SR was similar for both FS (100 and $96 \mathrm{~kg}$ of $\mathrm{BW} / \mathrm{t}$ of $\mathrm{DM}$ for the $\mathrm{HG}$ and HI systems, respectively).

The experimental area was a permanent grassland site containing greater than $80 \%$ perennial ryegrass (Lolium perenne). At the beginning of the farmlet study, 36 paddocks (0.89 ha on average) were grouped into 18 sets of 2 (balanced on location, pasture species, topography, drainage, distance from the milking parlor, and soil type) and randomly assigned to each FS. Cows were turned out to pasture immediately postpartum and grazed whenever weather conditions allowed, only returning indoors under severe weather conditions. Over the 3 -yr period, average lactation length was $275 \mathrm{~d}$ and grazing season length (defined as the number of days when grazed grass was included in the animal diet) was $270 \mathrm{~d}$, extending from early February to mid November. The application rate of artificial fertilizer was constant for both treatments at $200 \mathrm{~kg}$ of $\mathrm{N} /$ ha per year (and was applied in 8 equal applications from late February to late September). Grazing management practices were in accordance with Coleman (2009) and included weekly monitoring of farm grass cover with pasture quality maintained by removal of surplus grass throughout the experiment as silage (O'Donovan, 2000). A rotational grazing system was practiced, with the entire area of each farmlet available for grazing in the spring and autumn, and growth rates for each week of the year were derived by calculating the net herbage accumulation on ungrazed paddocks. Silage was removed from the area in early June (first cut) and mid July (second cut). Small surpluses were removed as bale silage as they occurred over the main growing season. Both FS were managed similarly on a common rotation length and grazed similar pregrazing herbage masses. Residency times were determined by the achievement of a target postgrazing residual sward height of $45 \mathrm{~mm}$. Total annual pasture production for each farmlet was calculated using the methodology of Coral and Fenlon (1978).

\section{Animal Measurements}

Cows were milked twice daily throughout lactation over the $3 \mathrm{yr}$ of the study. Milking took place at 0730 and $1530 \mathrm{~h}$ daily. Weekly milk production was derived from individual cow milk yield $(\mathrm{kg})$ recorded at each milking. Milk fat, protein, and lactose concentrations were determined in successive p.m. and a.m. samples of milk each week using a Milkoscan 203 (Foss Electric, Hillerød, Denmark) and weekly milk solids (MS) were calculated. Lactation milk and MS production per hectare were calculated by multiplying total lactation yields by the annual SR for each genotype and FS each year. Cow BW were recorded weekly upon exit from the milking parlor using an electronic scale (TruTest Ltd., Auckland, New Zealand) calibrated weekly against known weights. Cow BCS was measured every 3 wk throughout the study using a scale from 0 to 5 scale $(0=$ thin, $5=$ fat $)$ in increments of 0.25 as outlined by Edmonson et al. (1989). Body condition was assigned by the same individual throughout the study.

The herd had a mean calving date of March 1 in each of the $3 \mathrm{yr}$ of the study. Approximately $10 \mathrm{~d}$ before the commencement of the breeding period, each cow was examined using transrectal ultrasound imaging (Aloka SDD $500 \mathrm{~V}$ scanner with a $5-\mathrm{MHz}$ transducer, Aloka Ltd., Tokyo, Japan) to detect ovarian or uterine disorders and to ensure the cows had re-established ovarian activity. Cows with reproductive disorders (such as endometritis, pyometra, or ovarian cysts) were treated as necessary using standard veterinary procedures. For the duration of the breeding season, cows were observed for estrus 4 times daily (0630, 1200, 1500, and 2000 h). Tail paint was used as a heat detection aid and was reapplied when necessary. Cows were inseminated following signs of heat using AI over a 13-wk breeding period, which commenced in late April each year. During the breeding season, all cows showing signs of heat were inseminated regardless of calving date. The same professional inseminator performed AI for each year of the study. Cows detected in heat before morning milking (0630 h) were inseminated that morning, whereas cows detected later that day were inseminated the following morning. Ultrasonographic examination was conducted at approximately 30 to $37 \mathrm{~d}$ after the conclusion of the breeding season to determine pregnancy status and overall pregnancy rates.

\section{Statistical Analyses}

The effects of FS on total lactation yields for milk, MS, milk composition, calving to first service interval, and calving to conception interval were determined using mixed models (Proc Mixed; SAS Institute, 2006) with cow included as a repeated effect to account for the repeated lactations per cow; a compound symmetry covariance structure with heterogeneous variances provided the best fit to the data. Initial models included the effects for FS, parity, year, breed, calving date, and 
interactions. Nonsignificant effects $(P>0.05)$ were removed from the models by backward elimination. Number of services per cow was analyzed using the KruskalWallis nonparametric test (PROC NPAR1WAY; SAS Institute, 2006). Binary data (pregnancy rate to first and second service, 42-d pregnancy rate, submission rate, and overall pregnancy rates) were analyzed using chi-squared analysis (PROC FREQ; SAS Institute, 2006 ) over the $3 \mathrm{yr}$ of the project.

\section{Economic Analysis}

The Moorepark Dairy Systems Model (MDSM; Shalloo et al., 2004b), a stochastic budgetary simulation model, was used to simulate a model farm integrating biological data for each feed system. The model was used to quantify the economic implications of feed system on farm profitability at different milk prices and for a static herd size. The MDSM integrates animal inventory and valuation, milk production, feed requirement, land and labor utilization and economic analysis. Grass utilization was calculated by the MDSM to meet the net energy requirements for maintenance, milk production, and BW change across lactation (Jarrige, 1989) minus energy requirements supplied through concentrate supplementation. Variable costs (fertilizer, contractor charges, medical and veterinarian, AI, silage, and reseeding), fixed costs (machinery maintenance and running costs, farm maintenance, car, telephone, electricity, and insurance) and sales values (milk, cull cow, and calf) were based on prices at the time of the experiment (Teagasc, 2008). The herds were compared across 3 future base milk prices of 22,27 , and $33 €$ cents per liter $(\mathbf{\epsilon} \mathbf{c} / \mathbf{L})$, assuming reference milk content of $33.0 \mathrm{~g} / \mathrm{kg}$ protein and $36.0 \mathrm{~g} / \mathrm{kg}$ fat and a relative milk price ratio of 1:2 for fat:protein.

The key default herd parameters used in the model farm are shown in Table 1 . All calves were sold at 1 mo of age. All male and female calves were assumed sold for market values of $€ 108$ and $€ 320$, respectively. Replacement females were bought for $€ 1,540$ based on market conditions 1 mo before calving. Labor costs were calculated based on the methodology reported by Shalloo et al. (2004b) based on a labor requirement of $48 \mathrm{~h}$ per cow $\mathrm{yr}^{-1}$, whereas $1,848 \mathrm{~h}$ was considered equal to 1 labor unit per year, at a cost of $€ 22,855$.

Two economic scenarios were investigated within the model for a fixed farm size of 40 ha. In scenario 1 (S1), it was assumed that farmers were constrained by cow numbers; that is, restriction on stock-carrying capacity and herd size was fixed at 100 cows. In S1, increased feed input results in an increase in milk production per animal. In scenario 2 (S2), it was assumed that farmers were constrained by land area and would therefore carry sufficient numbers of dairy stock based on a fixed land area of 40 ha, equivalent to the average dairy holding within the Irish dairy industry (fixed land area). In this scenario, output could be increased through increased feed input facilitating increased stocking density on the 40-ha dairy platform. For each scenario, farm profit was estimated using the actual milk production and fertility data from the experiment.

\section{Risk Analysis}

Whole-farm stochastic budgets are similar to ordinary budgets except that uncertainty in some normally distributed variables in the budget is recognized and taken into account (Milham, 1998). Hardaker et al. (1997) stated that the selected variables to be added stochastically are usually those that will have the largest effect on the level of risk of a certain outcome. Stochastic budgeting using Monte Carlo simulation was used to investigate the effect of milk price, concentrate cost and replacement heifer costs variation on the financial outcomes of the study while the approach taken has previously been outlined by McCarthy et al. (2007). The most likely (minimum to maximum) values selected (based on expert opinion) were $€ 200$ (€150 to $€ 250$ ) per tonne for concentrate costs, $€ 0.27$ ( $€ 0.22$ to €0.33) per liter for milk price, and €1,540 (€1,340 to $€ 1,740)$ for replacement heifer costs. A cumulative density function (CDF) was created to represent the influence of variation in milk price, concentrate costs, and replacement heifer costs on farm net profit. The output distribution was set at total farm profitability, which was a function of total receipts from milk, calves, and cull cows less all variable and fixed costs (including labor).

\section{RESULTS}

\section{Climate and Grass Production}

Table 2 shows the seasonal variation in climatic conditions for the $3 \mathrm{yr}$ of the study. Average total annual

Table 1. Herd default parameters used in the Moorepark dairy systems model

\begin{tabular}{lc}
\hline Parameter & Amount \\
\hline Farm size $($ ha $)$ & 40.0 \\
Concentrate cost $(€ / \mathrm{t})$ & 200 \\
Opportunity cost of land $(€ /$ ha $)$ & 267 \\
Cow housing costs $(€ /$ cow $)$ & 1,500 \\
Fertilizer: urea $(€ / \mathrm{t})$ & 340 \\
Fertilizer: calcium, ammonium, nitrate $(€ / \mathrm{t})$ & 300 \\
Ratio value of protein to fat & $2.6: 1$ \\
Replacement heifer costs $(€)$ & 1,540 \\
Labor costs $(€ /$ mo $)$ & 1,905 \\
\hline
\end{tabular}


rainfall was $975 \mathrm{~mm}$ (equivalent to $17.6 \mathrm{~mm} / \mathrm{wk}$ ). On a seasonal basis, average weekly rainfall was lowest in spring (February, March, and April) and summer (May, June, and July), highest in winter (November, December and January), and intermediate in autumn (August, September, and October). Solar radiation was highest in summer, lowest in winter, and intermediate in spring and autumn. Average maximum and minimum daily temperatures were $14.5^{\circ} \mathrm{C}$ and $6.5^{\circ} \mathrm{C}$, respectively, average soil temperature was $11.7^{\circ} \mathrm{C}$, and sward minimum temperature was $4.4^{\circ} \mathrm{C}$. Both average soil temperature and sward minimum temperature were highest in summer and lowest in spring. Total average annual herbage production over the 3 -yr period was $12,483(\mathrm{SE}=891) \mathrm{kg}$ of DM per hectare (Figure 1). In each year, grass growth exceeded animal requirements between mid April and mid September (with average daily growth of $78 \mathrm{~kg}$ of $\mathrm{DM} / \mathrm{ha}$ ), and $84 \%$ of total annual growth occurred during this period.

\section{Effect of FS on Milk Production and Reproductive Performance}

The effect of FS on total lactation milk production, $\mathrm{BW}, \mathrm{BCS}$, and reproductive performance over the 3-yr period are shown in Table 3 and Figure 2. Animals in the HI group had a higher milk (6,049 vs. 5,606 $\mathrm{kg}$ ), SCM (5,802 vs. 5,384 kg; Tyrrell and Reid, 1965), and fat (253 vs. $235 \mathrm{~kg}$ ), protein (205 vs. $192 \mathrm{~kg}$ ), and lactose $(278$ vs. $257 \mathrm{~kg})$ yields. When the aggregated effects of increased concentrate supplementation and increased SR are considered, the systemic milk production response to increased concentrate supplementation in association with increased SR in the HI system was $1.53 \mathrm{~kg}$ of milk and $0.11 \mathrm{~kg}$ of fat plus protein per kilogram of additional concentrate fed at the higher SR.

Both systems of production achieved similar peak milk and peak MS production (Figure 2); however, the persistency of the HI production system was greater from peak to the end of lactation. The feed groups did not differ significantly with respect to milk composition. Feed system had no significant effect on reproductive

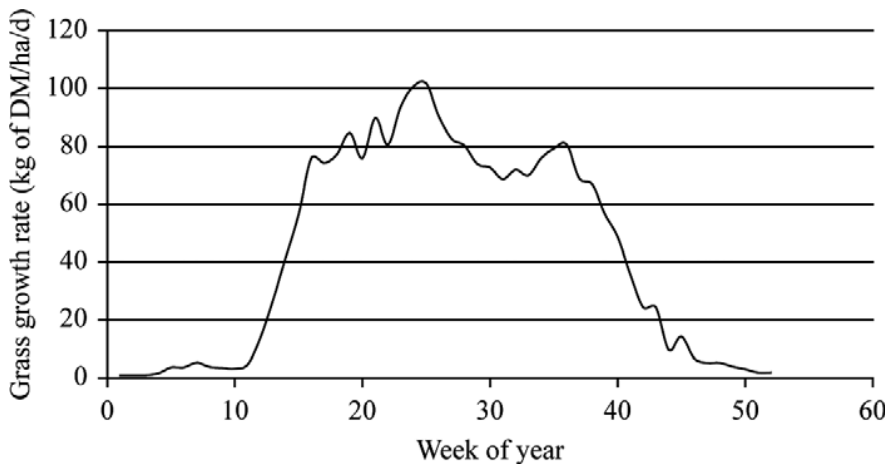

Figure 1. Seasonal variation in grass growth at Ballyhaise (Co. Cavan, Ireland) during 2005, 2006, and 2007.

performance, with similar calving to service interval, 24-d submission rate, pregnancy rate to first service, 6 -wk in-calf rate, 13 -wk empty rate, and services per cow for the $2 \mathrm{FS}$. Calving to conception interval was longer $(P=0.05)$ for the HI group (96 d) compared with the HG group (85 d). The effects of FS on BW and BCS over the entire study period are displayed in Table 4. Production systems did not differ in average lactation BW or BCS; however, animals in the HI FS were heavier and better conditioned $(P<0.10)$ at drying-off (611 kg and 2.93 BCS vs. $594 \mathrm{~kg}$ and 2.83, respectively).

\section{Effect of FS on Economic Performance}

The key herd output parameters from the model are shown in Table 5. In the fixed cow numbers scenario (S1), where an equal number of cows (100) were calved for each feed system, fat plus protein sales, herbage utilization, and concentrate input were higher for the HI system, whereas grazed grass eaten per cow was higher for the HG system. Replacement and fixed costs were similar for both HG and HI systems; however, increased feed supplementation in the HI system resulted in increased purchased feed, total variable costs, and total costs. When the HI system was allowed to increase in herd size in the fixed land scenario (S2), the increase in

Table 2. Seasonal deviation in meteorological characteristics at Ballyhaise research site during the study period $(2005,2006$, and 2007)

\begin{tabular}{lcrrrrc}
\hline Item & Spring & Summer & Autumn & Winter & SE $^{1}$ & Average $^{2}$ \\
\hline Average weekly rainfall $(\mathrm{mm})$ & 16.3 & 16.4 & 18.2 & 25.9 & 1.24 & 17.64 \\
Solar radiation $\left(\mathrm{J} / \mathrm{cm}^{2}\right)$ & 3,658 & 10,226 & 5,017 & 1,056 & 118.4 & 6,215 \\
Maximum daily temperature $\left({ }^{\circ} \mathrm{C}\right)$ & 9.75 & 17.5 & 15.5 & 8.8 & 0.142 & 14.5 \\
Minimum daily temperature $\left({ }^{\circ} \mathrm{C}\right)$ & 1.81 & 8.8 & 8.5 & 3.3 & 0.178 & 6.5 \\
Average soil temperature $\left({ }^{\circ} \mathrm{C}\right)$ & 4.3 & 15.3 & 13.0 & 5.1 & 0.11 & 11.68 \\
Sward minimum temperature $\left({ }^{\circ} \mathrm{C}\right)$ & -0.8 & 8.3 & 7.9 & 2.1 & 0.20 & 4.4 \\
${ }^{1}$ SE $=$ pooled standard error. & \multicolumn{7}{c}{} \\
${ }^{2}$ Average based on multiple rotations in summer and autumn and single rotations in spring and winter.
\end{tabular}


Table 3. Effect of system of production on milk production and reproductive performance

\begin{tabular}{|c|c|c|c|c|}
\hline \multirow[b]{2}{*}{ Item } & \multicolumn{2}{|c|}{ Feed system ${ }^{1}$} & \multirow[b]{2}{*}{$\mathrm{SE}^{2}$} & \multirow[b]{2}{*}{$P$-value } \\
\hline & HG & $\mathrm{HI}$ & & \\
\hline \multicolumn{5}{|l|}{ Milk production } \\
\hline Total milk yield ( $\mathrm{kg} / \mathrm{cow})$ & 5,606 & 6,049 & 165.8 & $<0.01$ \\
\hline SCM yield $(\mathrm{kg} / \mathrm{cow})$ & 5,384 & 5,802 & 156.8 & $<0.01$ \\
\hline Fat yield (kg/cow) & 235 & 253 & 7.6 & $<0.05$ \\
\hline Protein yield ( $\mathrm{kg} / \mathrm{cow})$ & 192 & 205 & 5.5 & $<0.05$ \\
\hline Lactose yield ( $\mathrm{kg} / \mathrm{cow})$ & 257 & 278 & 7.5 & $<0.01$ \\
\hline Fat $(\mathrm{g} / \mathrm{kg})$ & 41.9 & 41.8 & 0.93 & NS \\
\hline Protein $(\mathrm{g} / \mathrm{kg})$ & 34.2 & 33.9 & 0.40 & NS \\
\hline Lactose $(\mathrm{g} / \mathrm{kg})$ & 45.8 & 46.0 & 0.24 & NS \\
\hline \multicolumn{5}{|l|}{ Reproductive performance } \\
\hline Calving to service interval (d) & 74 & 81 & 5.3 & NS \\
\hline 24 -d submission rate $(\%)$ & 68 & 59 & & NS \\
\hline Calving to conception interval (d) & 85 & 96 & 5.9 & $<0.05$ \\
\hline Pregnancy rate to first service (\%) & 42 & 46 & & NS \\
\hline 6 -wk in-calf rate $(\%)$ & 41 & 45 & & NS \\
\hline 13 -wk empty rate $(\%)$ & 27 & 27 & & NS \\
\hline Services per cow (No./cow) & 1.79 & 1.77 & & NS \\
\hline
\end{tabular}

${ }^{1} \mathrm{HG}=$ high grass: low-input pasture system; $\mathrm{HI}=$ high intensity: high output per hectare system.

${ }^{2} \mathrm{SE}=$ pooled standard error.

herd size of 17 cows increased fat plus protein sales, and increased replacement, purchased feed, total variable costs, total fixed costs, and total costs compared with both HG and $\mathrm{HI}$ in $\mathrm{S} 1$.

a)

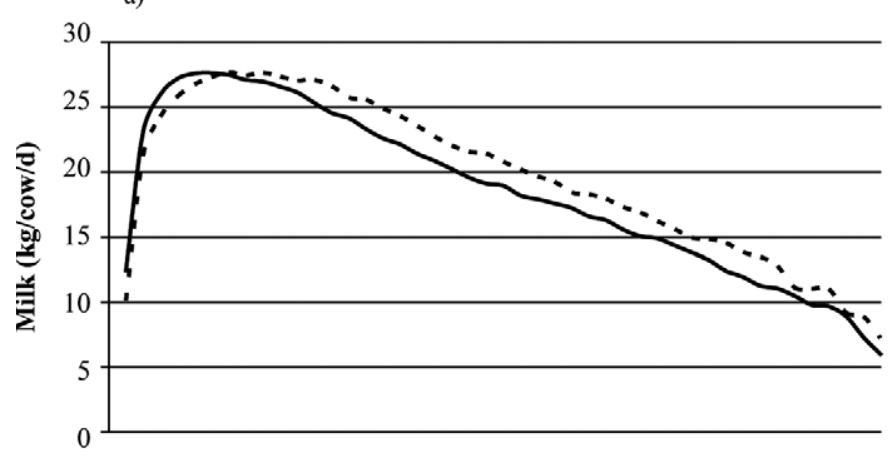

b)

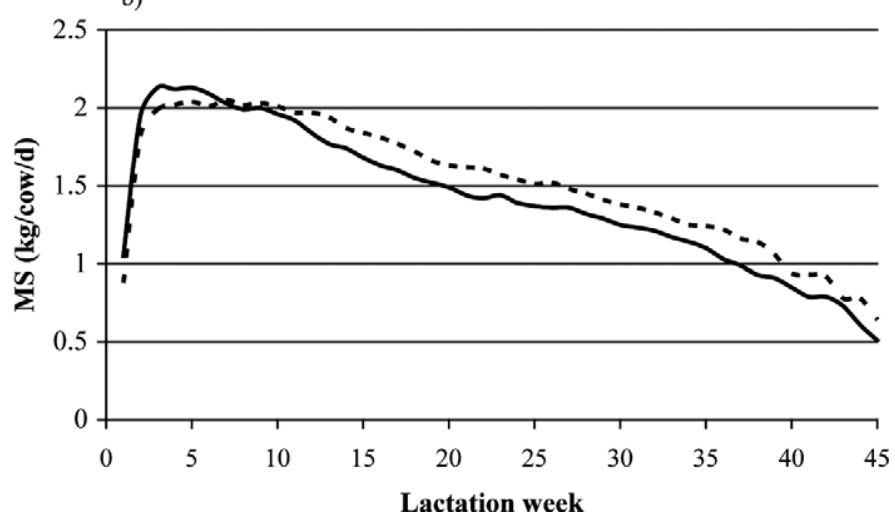

Figure 2. (a) Milk and (b) milk solids (MS) production lactation curve characteristics of the high grass $(-)$ and high concentrate (----) systems of milk production.
The effects of FS and production scenario on farm profitability are outlined in Table 6 . At all milk prices $(22,27$, and $33 € \mathrm{c} / \mathrm{L}$ ) and in both scenarios (S1 and S2), milk receipts were greater for the HI system. At a milk price of $27 € \mathrm{c} / \mathrm{L}$, profit per cow, per kilogram of MS, and per hectare were similar for HG and $\mathrm{HI}$ in S1 and higher for $\mathrm{HI}$ in S2. At a milk price of $22 € \mathrm{c} / \mathrm{L}$, all systems were unprofitable, with increased losses realized in the HI system (both S1 and S2) compared with the HG system. In contrast, at a milk price of 33 €c/L, profit per cow, per kilogram of MS, and per hectare were higher in the HI system, with a higher profit realized in S2.

Stochastic budgeting showed a mean total farm profit of $€ 27,159$ and $€ 28,108$ when cow numbers were fixed in the HI and HG systems, respectively, whereas mean farm profit was €33,864 for HI when land area was fixed in S2. The range in farm profit with a $90 \%$ CI (0.05 and 0.95) was greater for the HI system under both fixed land (-€1,860 to €68,497) and fixed cow numbers ( $-€ 3,294$ to $€ 56,426)$ assumptions compared with HG in S1 (€440 to €54,856). Figures 3a and 3b show the CDF of the influence of variation in milk price, concentrate costs, and replacement heifer costs on farm net profit. The CDF functions represent the economic outcomes distribution against the prospect of risk to that system. As the CDFs cross over, the cumulative probability distribution shows that first-degree stochastic dominance cannot be used to determine the optimum system of milk production. Therefore, seconddegree stochastic dominance must be used, which takes into account the farmer's aversion to risk when deciding on the optimum system of milk production. 
PATTON ET AL.

Table 4. Effect of system of milk production on BW and BCS

\begin{tabular}{|c|c|c|c|c|}
\hline \multirow[b]{2}{*}{ Item } & \multicolumn{2}{|c|}{ Feed system ${ }^{1}$} & \multirow[b]{2}{*}{$\mathrm{SE}^{2}$} & \multirow[b]{2}{*}{$P$-value } \\
\hline & HG & HI & & \\
\hline BW average $(\mathrm{kg})$ & 569 & 573 & 9.39 & NS \\
\hline BW at breeding $(\mathrm{kg})$ & 571 & 556 & 13.47 & NS \\
\hline BW at drying off (kg) & 594 & 611 & 9.64 & 0.07 \\
\hline BCS average & 2.91 & 2.93 & 0.392 & NS \\
\hline BCS at breeding & 2.90 & 2.92 & 0.043 & NS \\
\hline BCS at drying off & 2.83 & 2.93 & 0.045 & $<0.05$ \\
\hline
\end{tabular}

\section{DISCUSSION}

The productivity and subsequent profitability of a pasture-based dairy system is determined by the environment (especially feeding) in combination with the inherent genetic capabilities (production and health traits) of the herd (Holmes et al., 2002). A farmlet study such as this experiment allows greater feeding and management control than a large population study, where it is difficult to account for the influences of onfarm decisions. Consequently, this data set provides a unique opportunity to investigate the productivity and financial performance of alternate systems of milk production. This study compares 2 intensive pasturebased systems on a wetland soil with impeded drainage, and the results observed further substantiate the large influence of FS on the profitability of pasture-based production systems.

Pasture growth and utilization are appreciably influenced by soil type, nutrient status, and climatic conditions (Brereton, 1995). Compared with conditions in the south of Ireland (Dillon et al., 2005), increased winter rainfall coupled with heavy clay soil characteristics in the BMW region adversely affect soil trafficability, especially in late autumn and early spring (Shalloo et al., 2004a). The results of the present study show that, compared with the results of Dillon et al. (2005), overall pasture growth ( $t$ of $\mathrm{DM} /$ ha per year) at Ballyhaise was similar to that at the Teagasc Research site at Moorepark, Co. Cork $\left(52^{\circ} 07^{\prime} \mathrm{N}, 08^{\circ} 16^{\prime} \mathrm{W}\right)$ in the south of Ireland. However, substantial differences were found in the seasonal distribution of herbage production, with lower growth in spring, autumn, and winter (due to comparably lower soil temperatures) and a later, higher, and more persistent peak growth rate during summer and autumn (due to increased moisture availability). Dillon et al. (2005) reported total annual herbage production of $13.9 \mathrm{t}$ of $\mathrm{DM} /$ ha per year for the site at Moorepark compared with $12.4 \mathrm{t}$ of DM/ ha per year for Ballyhaise during the 3 yr of this study. Although early season pasture production (February and March) was $32 \%$ lower at Ballyhaise (20.2 vs. 29.6 $\mathrm{kg}$ of $\mathrm{DM} /$ ha per day), summer and autumn growth was consistently higher (14.8 and $46.1 \%$, respectively) than that reported by Dillon et al. (2005) for the Teagasc campus at Moorepark. The lower spring growth on more northerly sites has been reported previously (Brereton, 1995) due to lower spring temperatures and reduced solar radiation, whereas the higher relative summer and autumn growth rates at Ballyhaise may

Table 5. Key herd output characteristics and costs in a fixed cow number scenario and a limited land area scenario in the HG and HI feed systems ${ }^{1}$

\begin{tabular}{|c|c|c|c|}
\hline \multirow[b]{2}{*}{ Item } & \multicolumn{2}{|c|}{ Fixed cows } & \multirow{2}{*}{$\frac{\text { Fixed land }}{\text { HI }}$} \\
\hline & $\mathrm{HG}$ & $\mathrm{HI}$ & \\
\hline Cows calving $(\mathrm{n})$ & 100 & 100 & 117 \\
\hline Milk solids ${ }^{2}$ sales $(\mathrm{kg})$ & 42,016 & 45,354 & 53,064 \\
\hline Herbage utilized ( $\mathrm{kg}$ of $\mathrm{DM} / \mathrm{ha}$ ) & 11,098 & 12,029 & 12,029 \\
\hline Grazed grass (kg of DM/cow) & 3,726 & 3,403 & 3,403 \\
\hline Grass silage (kg of DM/cow) & 1,033 & 927 & 927 \\
\hline Concentrate $(\mathrm{kg}$ of $\mathrm{DM} / \mathrm{cow})$ & 577 & 1,365 & 1,365 \\
\hline Replacement costs $(€)$ & 47,967 & 47,967 & 56,122 \\
\hline Purchased feed costs $(€)$ & 11,968 & 28,323 & 33,138 \\
\hline Total variable costs $(€)$ & 90,283 & 103,400 & 122,796 \\
\hline Total fixed costs $(€)$ & 55,069 & 55,269 & 62,262 \\
\hline Total costs $(€)$ & 166,070 & 179,457 & 207,878 \\
\hline
\end{tabular}

${ }^{1} \mathrm{HG}=$ high grass: low-input pasture system; $\mathrm{HI}=$ high intensity: high output per hectare system.

${ }^{2}$ Fat plus protein yield. 
a)
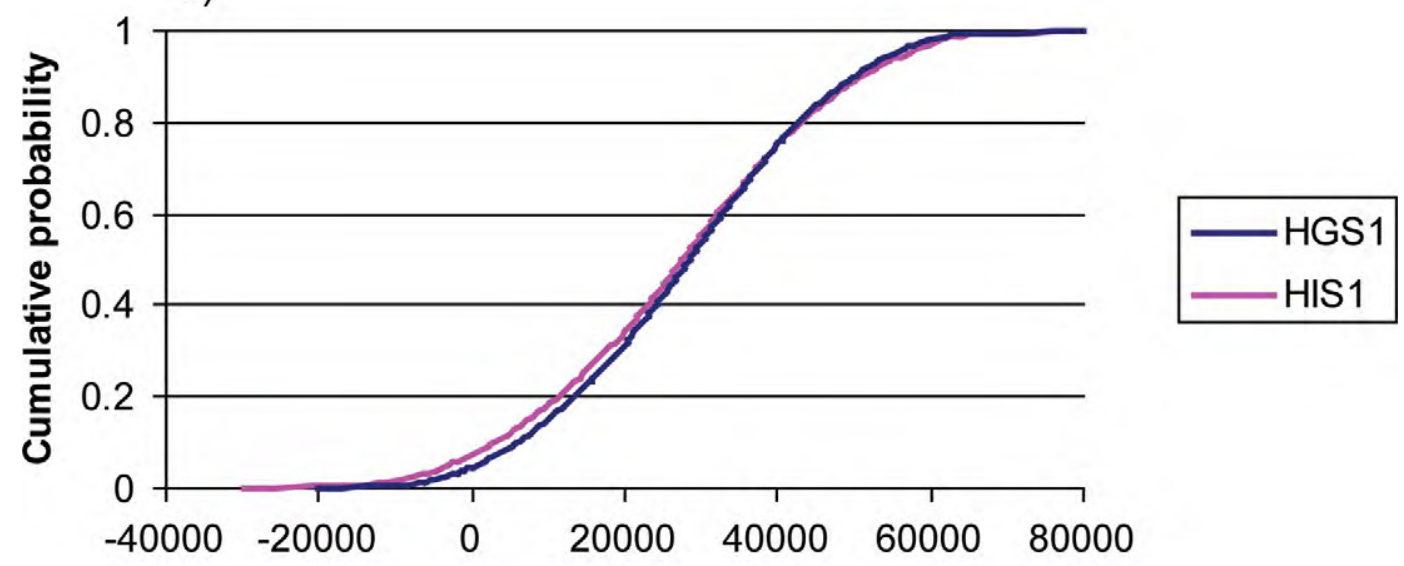

b)
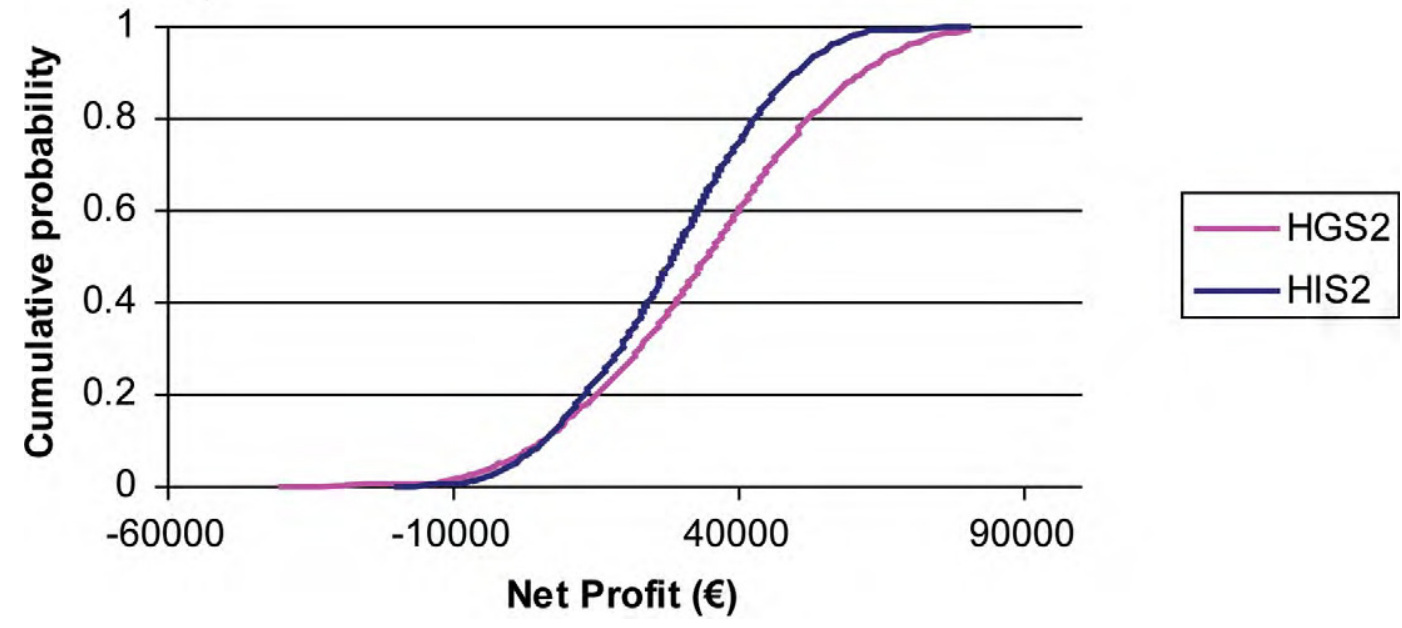

Figure 3. Cumulative probability function showing the influence of milk price, concentrate costs, and replacement heifer costs on net farm profitability for the high grass (low-input pasture; HG) system and high intensity (high output per hectare; HI) system in (a) a scenario in which cow numbers are fixed to a herd size of 100 cows (S1) and (b) a scenario in which cow land area is fixed at 40 ha (S2). Color version available in the online PDF.

relate to the increased moisture retention capacity of clay drumlin soils compared with the light loamy soils at the Moorepark site (Brereton and Hope-Cawdrey, 1988). The lower winter and spring growth required that, compared with spring production systems in the south of Ireland (Coleman, 2009), feed demand in early spring was reduced at Ballyhaise by delaying the start of calving and supplementing the herd with additional concentrate in early lactation to achieve synchrony between feed supply and demand to achieve high performance during the experiment.

\section{Milk Production, BW, BCS,} and Reproductive Performance

The success of a pasture-based system depends on achieving a balance between pasture growth and feed demand by the grazing animals (Holmes et al., 2002). Although concentrate supplements are generally offered to pasture-fed dairy cows to alleviate shortfalls in herbage DMI, increased SR post-EU milk quota are likely to result in more frequent and prolonged periods of pasture deficit (Cacho and Bywater, 1993) and a consequential requirement for more efficient pasture management and concentrate supplementation strategies, particularly on wetland soils. The intensity of production within the current experiment is exemplified by the high comparative SR (MacDonald et al., 2008) of both FS. One of the main objectives of supplementing grazing dairy cows is to increase total DMI relative to that of pasture-only diets (Peyraud and Delaby, 2001). The higher total lactation milk, SCM, fat, protein, and lactose yields achieved with the HI group was expected, given the large increase in energy supply with this FS. 
Table 6. The effects of feed system and milk price on economic performance for a 40-ha farm at the Ballyhaise site in a fixed cow number scenario and a limited land area scenario in the HG and HI feed systems ${ }^{1}$

\begin{tabular}{|c|c|c|c|}
\hline \multirow[b]{2}{*}{ Item } & \multicolumn{2}{|c|}{ Fixed cows } & \multirow{2}{*}{$\frac{\text { Fixed land }}{\mathrm{HI}}$} \\
\hline & $\mathrm{HG}$ & HI & \\
\hline \multicolumn{4}{|l|}{ Base milk price: $27 €$ cent/L } \\
\hline Milk sales $(€)$ & 162,833 & 175,354 & 205,165 \\
\hline Profit per cow $(€)$ & 301 & 293 & 311 \\
\hline Profit per $\mathrm{kg}$ of milk solids ${ }^{2}(€$ cent) & 0.72 & 0.65 & 0.69 \\
\hline Profit per hectare $(€)$ & 753 & 734 & 911 \\
\hline \multicolumn{4}{|l|}{ Base milk price: $20 €$ cent/L } \\
\hline Milk sales $(€)$ & 120,418 & 129,648 & 151,688 \\
\hline Profit per cow $(€)$ & -126 & -167 & -149 \\
\hline Profit per kg of milk ( $€$ cent) & -0.30 & -0.37 & -0.33 \\
\hline Profit per hectare $(€)$ & -314 & -416 & -435 \\
\hline \multicolumn{4}{|l|}{ Base milk price: $33 €$ cent $/ \mathrm{L}$} \\
\hline Milk sales $(€)$ & 199,199 & 214,541 & 251,013 \\
\hline Profit per cow $(€)$ & 667 & 688 & 706 \\
\hline Profit per kg of milk ( $€$ cent) & 1.59 & 1.52 & 1.56 \\
\hline Profit per hectare $(€)$ & 1,668 & 1,720 & 2,064 \\
\hline
\end{tabular}

The efficiency of concentrate supplementation expressed in terms of the observed milk production response (Faverdin et al., 1991; Bargo et al., 2002) was low within the HI FS of the current experiment, as evidenced by a response to concentrate supplementation of $0.56 \mathrm{~kg}$ of milk $/ \mathrm{kg}$ of concentrate supplementation. Pasture management (allowance, height, species, herbage mass, and quality), supplementation strategy (amount and type fed), and animal genetic potential for milk production are widely considered to be among the most important factors affecting milk response to concentrate supplementation (Delaby et al., 2001; Bargo et al., 2003; Kennedy et al., 2007). The low response evident in this study is consistent with the previous findings when using animals of similarly low to moderate genetic potential for milk production (Kennedy et al., 2003; Horan et al., 2005). Both Delaby et al. (2001) and Dillon et al. (2006) concluded that the relatively low milk production response to concentrate supplementation among such animals was due mainly to a greater substitution rate (i.e., decrease in grass intake per unit of additional concentrate feed), whereas Kennedy et al. (2003) concluded that concentrate supplementation of low-genetic-potential animals for milk production was consequently uneconomical.

The comparably high system (or per hectare) response to a combination of increased SR and concentrate supplementation of $1.53 \mathrm{~kg}$ of milk $/ \mathrm{kg}$ of additional concentrate at the higher SR is similar to that reported previously (Coleman, 2009; Baudracco et al., 2010). The results of this study demonstrate that inclusion of supplements, with a concomitant increase in SR, can have synergistic effects in improving the productiv- ity of grazing dairy systems by achieving high pasture utilization in addition to high per animal production performance. The productive advantage of the HI system with an increased overall SR has been observed previously (Journet and Dermarquilly, 1979; MacDonald et al., 2008), and a recent meta-analysis review of SR studies (McCarthy et al., 2011) has suggested that an increase in SR of 1 cow per hectare results in an increase in milk production per hectare of $18 \%$. The results further substantiate the hypothesis of Kellaway and Porta (1993), who suggest that concentrate supplementation could facilitate increased SR to increase the efficiency of milk production per unit of land.

The overall level of reproductive efficiency observed within the study was low but similar to that reported previously by Coleman (2009) for low-EBI HolsteinFriesian animals. The hypothesis in the present study was that the cows in the HI FS would be in less-severe negative energy balance in early lactation and would return to positive energy balance at an earlier stage of lactation than the cows in the HG FS. Feed system had no effect on BW or BCS in early lactation, and similar to Horan et al. (2005), animals on the high energy diet (HI FS) did gain significantly more BW and BCS from breeding to drying off. Roche et al. (2006) also observed that increased energy intake (achieved in the HI FS of the current study) only increases BW and BCS from mid to late lactation compared with unsupplemented animals, whereas McCarthy et al. (2007) and Walsh et al. (2008) reported earlier nadir BW and BCS and greater BW and BCS gain between nadir and the end of lactation among animals fed increased levels of supplementation. In agreement with results from 
previous long-term studies at this institute (Kennedy et al., 2003; Coleman, 2009), feed system, although increasing animal performance and BW and BCS from mid lactation, had no significant effect on reproductive performance. Our results suggest that offering higher levels of concentrate supplementation may not alleviate the reduced reproductive performance of animals of low genetic potential for reproductive traits.

\section{Economic Performance}

The optimum production system is that which gives the highest profit per unit of the most limiting input (Kahi et al., 1998), which, in Irish pasture-based systems (following abolition of EU milk quotas) is farmland (O'Donnell et al., 2008). The CDF (Shalloo et al., 2004b) represent the economic outcomes distribution against the prospect of risk to that system and indicate that the optimum system of production depends greatly on the prevailing economic environment (Hodgson and Maxwell, 1981) as well as the relative availability of the key factors of production (e.g., land, herd size limits). Within a limited herd size scenario (S1), profit is maximized when production is achieved at minimum cost (HG system) at low milk prices and when strategic concentrate supplementation is accompanied by an overall increase in SR (HI system) at high milk prices. The limitation on output within a fixed herd size scenario results in more emphasis being put on efficiency for each kilogram of MS produced; consequently, in a low milk price situation, pasture-based systems are also more favorable, through their capability for low-cost milk production. The increased financial loss of the HI system compared with the lower cost HG system at low milk prices is consistent with previous findings (Shalloo et al., 2004c; McCarthy et al., 2007) and is due mainly to increased substitution of cheap pasture for higher cost concentrate, resulting in an increase in overall feed costs within HI systems. Similar to those of McCarthy et al. (2007), the results of this study indicate that where adequate feed exists (and cow numbers are fixed similarly to S1), additional concentrate supplementation will reduce profitability at low milk prices and increase profitability at higher milk prices.

The results of the present study indicate that the efficacy of increased supplementation to remove the constraints of pasture seasonality are greatly enhanced at higher milk prices because increased quantities of high-value milk are achieved within such systems. Similarly, Hodgson and Maxwell (1981) concluded that supplement and milk prices determined the optimum system for production. Although the HI feed system had an increased overall SR and herd size in
S2, thereby incurring increased feed, stock turnover, labor, and housing-related costs, these additional costs were compensated by the greater milk returns achieved compared with the HG feed system. These results suggest that when land availability is the primary limiting factor of production and concentrate supplementation is used strategically to increase SR without reducing pasture utilization, the financial efficiency of pasturebased systems can be enhanced at medium to high milk prices. The results observed further substantiate the hypothesis of Kellaway and Porta (1993), who suggest that concentrate supplementation in combination with increased SR could facilitate increased efficiency of milk production per unit of land.

Although the overall profitability of the systems investigated within this study were significantly lower than those reported by McCarthy et al. (2007), the comparably higher replacement costs provide the greatest cost differential between this study and that of McCarthy et al. (2007) and indicate that suboptimal reproductive performance is responsible for significant financial loss within the experiment, regardless of feeding treatment. The similarity in feed-related costs between the current study and that of McCarthy et al. (2007) indicates that high profit milk production is feasible on wetter, northern drumlin soils in the BMW region, where a high proportion of grazed grass is incorporated in the diet of the dairy herd and overall farm SR is matched to the pasture growth characteristics of the site.

\section{CONCLUSIONS}

The purpose of this study was to compare the biological and economic efficiencies of pasture-based production systems differing in concentrate supplementation level and stocking density on a wetland soil. Large variation in animal performance and farm profitability arises from alternate production systems depending on milk price and the individual limitations of the farm. The results of this study show that pasture-based systems of milk production in the northern region of Ireland are capable of highly efficient and profitable milk production and that the efficacy of increased supplementation to remove the constraints of pasture seasonality will depend on the price of supplementation and the price paid for additional milk produced.

\section{ACKNOWLEDGMENTS}

We acknowledge the financial support of the Irish Dairy Levy and we thank the staff of Ballyhaise College (Co. Cavan, Ireland) for their cooperation, care, and management of the experimental cows. 


\section{REFERENCES}

Bargo, F., L. D. Muller, J. E. Delahoy, and T. W. Cassidy. 2002. Milk response to concentrate supplementation of high producing dairy cows grazing at two pasture allowances. J. Dairy Sci. 85:17771792.

Bargo, F., L. D. Muller, E. S. Kolver, and J. E. Delahoy. 2003. Invited review: Production and digestion of supplemented dairy cows on pasture. J. Dairy Sci. 86:1-42.

Baudracco, L., N. Lopez-Villalobos, C. W. Holmes, and K. A. Macdonald. 2010. Effects of stocking rate, supplementation, genotype, and their interactions on grazing dairy systems: A review. N. Z. J. Agric. Res. 53:109-133.

Breen, J., and T. Hennessy. 2003. The impact of the MRT and WTO reform on Irish farms. FAPRI outlook 2003 Medium Term Analysis for the Agric.-Food Sector. Teagasc, Rural Economy Research Centre, Dublin, Ireland.

Brereton, A. J. 1995. Regional and year to year variation in production. Pages 12-22 in Irish Grasslands: Their Biology and Management. D. W. Jeffery, M. B. Jones, and J. H. McAdam, ed. Royal Irish Academy, Dublin, Ireland.

Brereton, A. J., and M. Hope-Cawdrey. 1988. Drumlin soils-The depression of herbage yields by shallow water table depth. Isr. J. Agric. Res. 27:167-178.

Cacho, O. J., and A. C. Bywater. 1993. Use of a grazing model to study management and risk. Proc. N.Z. Soc. Anim. Prod. 54:377-381.

Central Statistics Office (CSO). 2009. Principal Statistics in Relation to Agriculture. Central Statistics Office, Cork, Ireland.

Coleman, J. 2009. The influence of animal genetic potential across a variety of futuristic pasture-based systems of milk production. $\mathrm{PhD}$ Thesis. University College, Dublin, Ireland.

Coral, A. J., and J. S. Fenlon. 1978. A comparative method for describing the seasonal distribution of production from grasses. J. Agric. Sci. 91:61-67.

Delaby, L., J. L. Peyraud, and R. Delagarde. 2001. Effect of the level of concentrates supplementation, herbage allowance and milk yield at turn out on the performance of dairy cows in mid lactation at grazing. J. Anim. Sci. 73:171-181

Dillon, P., D. P. Berry, R. D. Evans, F. Buckley, and B. Horan. 2006. Consequences of genetic selection for increased milk production in European seasonal pasture-based systems of milk production. Livest. Sci. 99:141-158.

Dillon, P., J. R. Roche, L. Shalloo, and B. Horan. 2005. Optimising financial return from grazing in temperate pastures. Pages 131-147 in Utilization of Grazed Grass in Temporal Animal Systems. J. J. Murphy, ed. Wageningen Academic Publication, Wageningen, the Netherlands.

Edmonson, A. J. J., I. J. Lean, L. D. Weaver, T. Farver, and G. Webster. 1989. A body condition scoring chart for Holstein dairy cows. J. Dairy Sci. 72:68-78.

Faverdin, P., J. P. Dulphy, J. B. Coulon, R. Verite, J. P. Garel, J. Rouel, and B. Martquis. 1991. Substitution of roughage by concentrates for dairy cows. Livest. Sci. 27:137-156.

Hardaker, J. B., R. B. M. Huirne, and J. R. Anderson. 1997. Coping with Risk in Agriculture. CAB International, Wallingford, UK.

Hodgson, J., and T. J. Maxwell. 1981. Grazing research and grazing management. Pages 169-187 in HFRO Biennial Report 1979-1981. HFRO Penicuik, Midlothian, UK.

Holmes, C. W., I. M. Brookes, D. J. Garrick, D. D. S. Mackenzie, T. J. Parkinson, and G. F. Wilson. 2002. Milk Production from Pasture: Principles and Practices. Massey University, Palmerston North, New Zealand.

Horan, B., P. Dillon, P. Faverdin, L. Delaby, F. Buckley, and M. Rath. 2005. The interaction of strain of Holstein-Friesian cows and pasture-based feed systems on milk yield, body weight, and body condition score. J. Dairy Sci. 88:1231-1243.

Irish Cattle Breeding Federation (ICBF). 2005-2007. Irish cattle breeding statistics 2005. Irish Cattle Breeding Federation (ICBF).

Jarrige, R., ed. 1989. Ruminant Nutrition, Recommended Allowances and Feed Tables. John Libbey Eurotext, Montrougue, France.
Journet, M., and C. Demarquilly. 1979. Grazing. In Feeding Strategy for the High-Yielding Cow. W. H. Broster and H. Swan, ed. Granada, London, UK.

Kahi, A. K., I. S. Kosgey, V. L. Cardoso, and J. A. M. Van Arendonk. 1998. Influence of production circumstances and economic evaluation criteria on economic comparison of breeds and breed crosses. J. Dairy Sci. 81:2271-2279.

Kellaway, R., and S. Porta. 1993. Feeding concentrates supplements for dairy cows. Dairy Research and Development Corporation, Melbourne, Australia.

Kennedy, E., M. O'Donovan, F. P. O'Mara, J. P. Murphy, and L. Delaby. 2007. The effect of early-lactation feeding strategy on the lactation performance of spring-calving dairy cows. J. Dairy Sci. 90:3060-3070.

Kennedy, J., P. Dillon, P. Faverdin, L. Delaby, G. Stakelum, and M. Rath. 2003. Effect of genetic merit and concentrate supplementation on grass intake and milk production with Holstein-Friesian dairy cows. J. Dairy Sci. 86:610-621.

Lips, M., and P. Rieder. 2005. Abolition of raw milk quota in the European Union: A CGE analysis at the member country level. J. Agric. Econ. 56:1-17.

MacDonald, K. A., J. W. Penno, J. A. S. Lancaster, and J. R. Roche. 2008. Effect of stocking rate on pasture production, milk production, and reproduction of dairy cows in pasture-based systems. J. Dairy Sci. 91:2151-2163.

McCarthy, B., L. Delaby, K. M. Pierce, F. Journot, and B. Horan 2011. Meta-analysis of the impact of stocking rate on the productivity of pasture-based milk production systems. Animal 5:784794 .

McCarthy, S., B. Horan, P. Dillon, D. P. Berry, P. O'Connor, M. Rath, and L. Shalloo. 2007. Economic comparison of divergent strains of Holstein-Friesian dairy cows in various pasture-based production systems. J. Dairy Sci. 90:1493-1505.

McMeekan, C. P., and M. J. Walshe. 1963. The inter-relationships of grazing method and stocking rate in the efficiency of pasture utilization by dairy cattle. J. Agric. Sci. 61:147-166.

Milham, N. 1998. Technical report on the practice of whole-farm stochastic budgeting. NSW Agriculture, Armidale, Australia.

O'Donnell, S., L. Shalloo, A. M. Butler, and B. Horan. 2008. A survey analysis of opportunities and limitations of Irish dairy farmers. J. Farm Manag. 13:419-434

O'Donovan, M. 2000. The relationship between the performance of dairy cows and grassland management on intensive dairy farms in Ireland. PhD Thesis. University College, Dublin, Ireland.

Peyraud, J. L., and L. Delaby. 2001. Ideal Concentrate feeds for grazing dairy cows responses to supplementation in interaction with grazing management and grass quality. Pages 203-220 in Recent Advances in Animal Nutrition. P. C. Garnsworthy and J. Wiseman, ed. Nottingham University Press, Nottingham, UK.

Philpott, B. 1995. New Zealand Aggregate and Sectoral Productivity Growth 1960-1995. RPEP paper no. 274. Victoria University, Wellington, New Zealand.

Roche, J. R., D. P. Berry, and E. S. Kolver. 2006. Holstein-Friesian strain and feed effects on milk production, bodyweight and body condition score profiles in grazing dairy cows. J. Dairy Sci. $89: 3532-3543$

Ryan, M. 1974. Grassland productivity: 1. Nitrogen and soil effects on yield of herbage. Isr. J. Agric. Res. 13:275-291.

SAS Institute. 2006. Users Guide: Statistics. Version 9.1. SAS Institute Inc., Cary, NC.

Shalloo, L., P. Dillon, J. O'Loughlin, M. Rath, and M. Wallace. 2004a. Comparison of a pasture-based system of milk production on a high rainfall, heavy-clay soil with that on a lower rainfall, freedraining soil. Grass Forage Sci. 59:157-168.

Shalloo, L., P. Dillon, M. Rath, and M. Wallace. 2004b. Description and validation of the Moorepark Dairy System Model. J. Dairy Sci. 87:1945-1959.

Shalloo, L., J. Kennedy, M. Wallace, M. Rath, and P. Dillon. 2004c The economic impact of cow genetic potential for milk production and concentrate supplementation level on the profitability of 
pasture-based systems under different EU milk quota scenarios. J. Agric. Sci. 142:357-369.

Teagasc. 2008. Management data for farm planning. Teagasc, Dublin, Ireland.

Thomasson, A. J. 1979. The effect of drainage conditions on grassland production. Water control and grassland productivity. Pages 1.11.11 in Proc. Br. Grassl. Soc. winter meeting. British Grassland Society, Hurley, UK.

Tyrrell, H. F., and J. T. Reid. 1965. Prediction of the energy value of cows' milk. J. Dairy Sci. 48:1215-1233.
Walsh, S., F. Buckley, K. Pierce, N. Byrne, J. Patton, and P. Dillon. 2008. Effects of breed and feeding system and milk production, body weight, body condition score, reproductive performance, and postpartum ovarian function. J. Dairy Sci. 91:4401-4413.

Whetstone, L. 1999. The Perversity of Agricultural subsidies. Page 123 in Fearing Food, Risk, Health and Environment. J. Morris, R. Bate, ed. Butterworth Heinemann, London, UK. 